\title{
Cultural factors and sexual practices of women living with HIV / AIDS in South West, Nigeria.
}

\author{
Akinbebije, Christianah Olufunbi \\ College of Education, Open, Distance \& E Learning \\ Kampala International University, Uganda \\ Anumkaka, Blessing Ijeoma \\ College of Education, Open, Distance \& E Learning \\ Kampala International University, Uganda \\ Abba Dahiru \\ Department of educational Foundation \\ Kaduna Polyytechnic Kaduna, Nigeria
}

\begin{abstract}
The study examined the cultural factors and sexual practices of women living with HIV/AIDS in South West, Nigeria. Three states were chosen out of the six states in South West. One hundred and Eighty Three women living with HIV/AIDS were drawn from the three states. Descriptive survey research design was used for the study. A questionnaire titled "Questionnaire on women living with HIV/AIDS (QWLH/A)" was administered on the respondents. The findings revealed that there is high significant relationship between cultural factor and sexual practices in placing women on the risk of contracting HIV/AIDS. Based on the findings, it was recommended that government should introduce sex education for young Nigerians. The practice of widow inheritance can die slowly by testing both parties involved before the inheritance is carried out.
\end{abstract}

\section{INTRODUCTION}

Cultural and society have powerful effect and often increase women's vulnerability to HIV/AIDS. According to Kuti (1996), the battle against AIDS is a battle against the people's ingrained behavior. Cultural practices relating with sex have been feared to be the fasted means of spreading AIDS, most people according to Kuti are ready to bear any consequence to satisfy cultural imperative which they regard as their only line with the past of their ancestors.

In African societies and traditional beliefs, practices which are conducive to HIV/AIDS infections are in existence. Among those practices likely to increase the risk of HIV/AIDS transmission through sexual intercourse are remarrying of widow's early marriage, ritual sexual intercourse and rape. Other traditional practices that can increase the risk of HIV/AIDS transmission through blood or the sharing of contaminated instructions are female genital multination, excision and other ritual scarification and tattooing. 
Akinbebije, C. O., Anumkaka, B. I., \& Dahiru, A. (2020). Cultural factors and sexual practices of women living with HIV / AIDS in South West, Nigeria. Advances in Social Sciences Research Journal, 7(5) 91-95.

In Many cultures the premium placed on having children often leads to childhood marriage and early child bearing. Girls as young as age 10 are given to older men in marriage in order to cement friendships and economic ties between families. When girls are married to older men, they can be vulnerable to HIV and other diseases because their husbands usually have already had a number of sexual partners. Also the girls are mature to have sex but because they are given out, it leads them to Vesico Vaginal fistula. Social, Political and religious barriers often hide young wives from the world, while their husbands frequently have other sexual partners (Zabln and Kiragu, 1998).

The practice of a man having multiple wives occurs in some cultures. In African, when the husband seeks a new often younger wife he may have sexual contact with a number of women in the process and this risk bringing HIV home.

In recent times the traditional need for a substitute pregnant or nursing wife has become less important especially in South West Nigeria, partly because of the wide spread practice and adoption of contraception. (Orubuloye and Cald well 1993).

\section{STATEMENT OF THE PROBLEM}

Around the world and particularly in the south western part of Nigeria, a variety of cultural factor seems to have continued to increase women risk of HIV/AIDS. These practices and traditions affect women; more and more women continue to be infected.

Cultural practices prevent women from discussing sex or sexually transmitted infections. Women are more often reluctant or unable to enquire about sex for fear of being considered morally loose. Women are particularly vulnerable to HIV/AIDS, because they have limited social and cultural support to negotiate or act to protect themselves. Women culturally have little power to control the risky sexual behavior of their partners or take action to limit their sexual exposure. It is culturally acceptable for a man to marry more than one wife and even have concubine even if they are married, but it is not acceptable for a woman. There is therefore, a pressing need to investigate the relationship between cultural factors and the sexual practices of women living with HIV/AIDS so as to limit the impact of HIV/AIDS and understand the influence of cultural factors like widow inheritance, marriage practice, women's status and sexual practices of women.

\section{PURPOSE}

The purpose of the study was to determine relationship of cultural factors and sexual practices of women living with HIV/AIDS in South Western part of Nigeria.

The study would also find out the rate of involvement of women with these cultural factors.

\section{Hypothesis}

The following were raised to pilot the study

1. There is no significant relationship between widow inheritance and sexual practices among women living with HIV/AIDS.

2. There is no significant relationship between marriage practices and sexual practices among women living with HIV/AIDS.

3. There is no significant relationship between women status and sexual practices among women living with HIV/AIDS. 


\section{METHODOLOGY}

The descriptive survey design was used in the study. Registered women living with HIV/AIDS in Ekiti, Ondo and Osun State AIDS coordinating centres constituted the population of the study comprised 183 women selected using purposive sampling technique, Lie Abiye and state Hospital were selected in Ekiti state, Ministry of Health in conjunction with Ondo state AIDS coordinating centre were selected in Ondo state and living Hope care llesha was selected in Osun state.

A self-designed questionnaire and unstructured interview were used by the researcher to collect data for the study. The data collected were analyzed using the product moment correlation. The hypotheses raised were tested at 0.05 level of significant.

\section{RESULTS}

The results of the study are presented in the table below.

Hypothesis 1: there is no significant relationship between widow inheritance and sexual practices among women living with HIV/AIDS.

Table 1: Correlation table for widow inheritance and sexual practices

\begin{tabular}{|l|c|c|c|}
\hline Variables & $\mathbf{N}$ & r-calculate & r-table \\
\hline Widowing & 183 & 0527 & 0195 \\
\hline Sexual practices & 183 & & \\
\hline
\end{tabular}

Table 1: shows that $r$-calculated (0.527) is greater than $r$-table (0.195), hence, the null hypothesis is rejected. This means that there is a significant relationship between widow inheritance and sexual practices among women. This shows that widow inheritance with asexual practices can place women in the risk of contracting HIV/AIDS when practice with an HIV victim.

\section{Hypothesis 2: There is no significant relationship between marriage practice and sexual practices among women living with HIV/AIDS.}

Table 2: correlation table for marriage practice and sexual practices

\begin{tabular}{|l|c|c|c|}
\hline \multicolumn{1}{|c|}{ Variables } & $\mathbf{N}$ & r-calculate & r-table \\
\hline Marriage practice & 183 & & \\
\hline & & 0.0661 & 0.195 \\
\hline Sexual practices & 183 & & \\
\hline $\mathrm{P}<0.05$ & & & \\
\hline
\end{tabular}

Table 2: shows that $r$-calculated $(0.661)$ is greater than $r$-table $(0.195)$, there is high and positive relationship. Hence, the null hypothesis is rejected. This means that marriage practice has a significant with sexual practices in placing women on the risk of contracting HIV/AIDS. 
Akinbebije, C. O., Anumkaka, B. I., \& Dahiru, A. (2020). Cultural factors and sexual practices of women living with HIV / AIDS in South West, Nigeria. Advances in Social Sciences Research Journal, 7(5) 91-95.

\section{Hypothesis 3: There is no significant relationship between women's status and sexual practices among living with HIV/AIDS.}

Table 3: Correlation table for women's status and sexual practices

\begin{tabular}{|l|c|c|c|}
\hline \multicolumn{1}{|c|}{ Variable } & $\mathbf{N}$ & r-calculate & r-table \\
\hline Women's status & 183 & & \\
\hline & & 0.406 & 0.195 \\
\hline Sexual practices & 183 & & \\
\hline
\end{tabular}

$\mathrm{P}<0.05$

Table 3: revealed that the value $r$-calculated is greater than $r$-tabulated at a significant level of 0.05 which shows that the results is significant. There is average significant relationship between women's status and sexual practices. The null hypothesis which states that, there is no significant relationship between women's status and sexual practices is rejected.

\section{DISCUSSION}

The study revealed that widow inheritance has a significant relationship with sexual practices in the spread of HIV/AIDS among women in south western part of Nigeria. The study agrees with Oppong (1995) who stated that younger widows are of particular risk because they are more likely to have contracted the virus. Also the study agreed with AIDS Analysis Africa (1994) which says the practice encourages sexual practices and thereby put people on the risks of HIV/AIDS.

The study further revealed that marriage practice has a significant relationship with sexual practices in the spread of HIV/AIDS among women. Considering the view of Heise (1999) which says "Once the marriage is sealed with dowry, the woman is considered paid for" and often cannot leave her husband even if her husband's behavior place her at risk of HIV infection.

Also the study revealed that, there is a significant relationship between women's status and sexual practices among women living with HIV/AIDS. The findings is consistence with the earlier report of AMREF (1994) that said, a woman might think her husband has other sexual relationship but find this impossible to discuss because men expect women to be submissive and to be ignorant in sexual matters and this can place then on the risk of HIV/AIDS. Also the finding agrees with thee report of Moyo and Muller (2011) which states that the women did not know their husband and these can also place them on the risk of contracting HIV/AIDS.

\section{CONCLUSION AND RECOMMENDATION}

Based on the findings of the study, it is concluded that culture plays a significant role in the life of women. Also the society at large should take into cognizance some cultural factors that are correlated with sexual practices which can place women on the risk of getting HIV/AIDS. It was recommended that, prevention programme targeted at women must be embarked on which will enable women to protect themselves from the disease, but millions of them will be able to do so only when their male partners are also convinced of the need. 
Government must introduce sex education for young Nigerians. HIV/AIDS prevention message should be included in school curriculum. The practice of widow inheritance can die away slowly because it is easy to eliminate a custom that has persisted in a culture for so long, but the best approach is to take an HIV test before the inheritance is carried out.

\section{Reference}

African Medical Research Foundation (1994).Female adolescent health and sexuality In Kenyan Secondary Schools: A research report, Nairobi, Kenya.

AIDS Analysis Africa (1994):Property - Grabbing: Why Zambia needs stronger laws to protect widows rights. Vol. 4 No 4. Pg. 1,7

Heise. L and Ellsberg. M (1999). Ending violence against women.

Population Reports, series L, No 11 Battimore, Johns Hoplins -School of Public Health, Population information program Pg. 43

Kuti, R. (1996).AIDS, the role of traditional women right monitor. A journal of women justice. Jan-March 1996, volume 1 No 5.

Moyo, N. \& Muller, J.C (2011).The influence of cultural practices on the HIV/AIDS pandemic in Zambia His Teslogiese studies/theological studies 67(3), Art \#770, 5 pages.

Oppong, C.A (1995) .High price to pay: Fore education, subsistence or a place in the job market. Health translation Review pp.35-36.

Orubuloye, I. O, Caldwell, J. C and Caldwell P. C (1993). The role of religions leaders in changing sexual behavior in an era of AIDS. Pages 117-127 in sexual Networking and HIV/AIDS in West Africa ed.Health transition Reviews, Canberra: Australian National University.

zabin, L and Kiragu, K (1998).The health consequences of adolescentsexual and fertility behavior in sub-Saharan African: studies in family planning. 